\title{
FUS/DDIT3 Fusion Gene
}

National Cancer Institute

\section{Source}

National Cancer Institute. FUS/DDIT3 Fusion Gene. NCI Thesaurus. Code C99279.

A fusion gene that results from a chromosomal translocation $\mathrm{t}(12 ; 16)(\mathrm{q} 13 ; \mathrm{p} 11)$ which

fuses either the first 5, 7 or 8 exons of the FUS gene with exon 2 of the DDIT 3 gene. This rearrangement is associated with myxoid liposarcoma. 